\title{
NOISES AND NUISANCES IN BALTO-SLAVIC AND INDO-EUROPEAN LINGUISTICS
}

\author{
FREDERIK KORTLANDT
}

It is gratifying to see that Jay Jasanoff has now (2004) adopted my theory that "the Balto-Slavic acute was a kind of stød or broken tone" (p. 172), which I have been advocating since 1973. Unfortunately, his acceptance of my view is not based on an evaluation of the comparative evidence (for which see Kortlandt 1985a) but on his desire to derive Balto-Slavic "acute" and "circumflex" syllables from the "bimoric" and "trimoric" long vowels which he assumes for Proto-Germanic as the reflexes of the Indo-European "acute" and "circumflex" tones of the neogrammarians. Since the original "circumflex" was limited to Indo-European $V H V$ sequences, Jasanoff proposes a whole series of additional lengthenings yielding "hyperlong" vowels in Germanic, Baltic and Slavic, which still do not suffice to eliminate the counter-evidence (cf. Kortlandt 2004b: 14). The reason for this failure is his unwillingness to recognize that lengthened grade vowels are circumflex in Balto-Slavic (cf. Kortlandt 1997a). He loosely refers to analogy in order to account for the data without discussing the problems involved. The long vowel of $\mathrm{SCr}$. donijeh 'I brought' cannot be due to analogy because it is a unique type. The same holds for the neo-acute of Posavian zaklẽ 'I swore'. Similarly, there is no

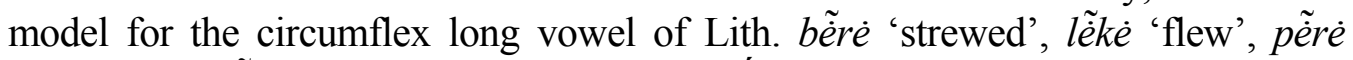
'thrashed', srẽ்e 'sipped' as opposed to gére 'drank', present tense gẽria like bẽria, lêkia, pẽria, srẽbia. The long vowel preterit continues the sigmatic aorist in this language (cf. Kortlandt 1985a: 114). Note that géré represents an original root aorist (cf. Vaillant 1966: 189f.), not the sigmatic aorist which Jasanoff presupposes (176). It is significant that Jasanoff does not come up with a single example of an acute lengthened grade vowel.

Jasanoff strongly objects to my rule that a laryngeal was lost after a lengthened grade vowel. Interestingly, he applauds a rule of monosyllabic lengthening and "circumflexion" in order to account for exactly the same instances. Since his acute is my laryngeal, we are in complete agreement here. The only difference is the chronology of the development, on which he is unclear and I am specific. The monosyllabic lengthening affected not only the sigmatic aorist but also the root aorist, e.g. Latin vēn-, Gothic qēm-, Toch. B śem 'came' $<{ }^{*} g^{w} \bar{e} m$ - (cf. Kortlandt 2004a: 9 and 14). Note that Eichner's law is a phantom (cf. Kortlandt 2003: 11), as is also clear from Latvian sầls 'salt' and gùovs 'cow'. The original distribution of lengthened grade in the 2 nd and 3rd sg. active forms of the sigmatic aorist and full 
grade in the other forms of the paradigm is still manifest in the Vedic injunctive (cf. Kortlandt 2004a: 7) and the Old Irish preterit (cf. Kortlandt 1997b: 135) as well as the Lithuanian future and the Slavic aorist. Vedic 1st sg. stoșam 'praise' and yosam 'separate' are full grade injunctive forms, not subjunctives (cf. Kortlandt 2004a: 8), and the same holds for jeșam, 1st pl. jeșma 'conquer'. All this is independent evidence which has to be taken into account in any serious treatment. The metatony in Lith. duõs 'will give' and kalbẽ s 'will speak' (for which see Kortlandt 2002) is not "trivially explainable by the normal phonological processes of Lithuanian" (thus Jasanoff, p. 176) and the nom.sg. ending $-\tilde{e}$ is not "a contraction product" (ibidem, cf. Kortlandt 1997c on the different types of $\bar{e}$-stem in Baltic). Note also that Jasanoff's reconstruction *nosi (174) is mistaken (cf. Stang 1957: 130 ) and that this form cannot be derived from *-eies, *-eiet because these would yield -ije, as in the nom.pl. form of the $i$-stems.

The history of Balto-Slavic accentuation is complex (see Kortlandt 1978 for an introduction). Jasanoff states that he was "consciously motivated by a desire to cut through the tangle of secondary hypotheses and "laws" that clutter the ground in the field of Balto-Slavic accentology" (171). It seems to me that by disregarding the work of Leskien, Hirt, Saussure, Meillet, Pedersen, Endzelin, Van Wijk, Būga, Nieminen, Dolobko, Hjelmslev, Stang, Dybo, Illič-Svityč, Zinkevičius, Winter and other scholars who have contributed to our knowledge and by proposing a wealth of arbitrary hypotheses for isolated pieces of evidence on the basis of what we find in other Indo-European languages one does not help to clarify the relevant issues. According to Jasanoff, my view that the broken tone of an acute vowel developed from a following laryngeal or preglottalized stop "is an extremely difficult position to maintain" because it implies that the rise of voicedness in the glottalic stops "was an independent change in every IE tradition" (172). This is nonsense, of course. If Jasanoff "is quite familiar with [my] views" (171), he must surely know that I reconstruct preglottalized voiced stops on the basis of the comparative evidence of Indo-Iranian, Balto-Slavic, Germanic and Italo-Celtic, supported by additional evidence from Greek and Armenian (see Kortlandt 1985b). It may be that Jasanoff should take the noises of his colleagues more seriously and avoid the nuisance of being caught in a tangle of data with which he is not familiar. Others might then profit from the reduction of noise in his writings and be spared the nuisance of having to repeat what can already be found in the scholarly literature.

\section{REFERENCES}

Jasanoff, Jay H. 2004 Balto-Slavic accentuation: telling news from noise. Baltistica 39/2, 171-177. Kortlandt, Frederik

1978 On the history of Slavic accentuation. Zeitschrift für vergleichende Sprachforschung 92, 269-281. 
1985a Long vowels in Balto-Slavic. Baltistica 21/2, 112-124.

1985b Proto-Indo-European glottalic stops: the comparative evidence. Folia Linguistica Historica 6/2, 183-201.

1997a PIE lengthened grade in Balto-Slavic. Festschrift for Eric P. Hamp, vol. II, 2631.

1997b Thematic and athematic verb forms in Old Irish. Sound law and analogy [Fs. Beekes], 133-137.

1997c Baltic $\bar{e}$ - and $\bar{l} / j \bar{a}$-stems. Baltistica 32/2, 157-163.

2002 Shortening and metatony in the Lithuanian future. Baltistica 37/1, 15-16.

2003 Initial laryngeals in Anatolian. Orpheus 13, 9-12.

2004a Accent and ablaut in the Vedic verb. Indo-Iranian Journal 47/1, 7-15.

2004b Balto-Slavic accentuation: some news travels slowly. Baltistica 39/1, 13-17.

Stang, Christian S.

1957 Slavonic accentuation (Oslo: Universitetsforlaget).

Vaillant, André

1966 Grammaire comparée des langues slaves, tome III: Le verbe (Paris: Klincksieck). 